\title{
Commodification of the gospel and the socio-economics of neo-Pentecostal/Charismatic Christianity in Ghana
}

\author{
Francis Benyah \\ Research Assistant \\ Young Adults and Religion in a Global Perspective (YARG) Project, \\ University of Ghana, Legon, Ghana \\ Email: fbenyah87@gmail.com
}

Submitted: April 17, 2018 / Accepted: October 25, 2018 / Published: December 3, 2018

\begin{abstract}
In Africa, religion, generally, has often been used as a medium to assuage difficulties in life. The pragmatic-oriented function of religion, as found in Africa's economy of faith, makes religion a kind of an economic good/service that can be harnessed to deal with existential needs and aspirations. Operating within this worldview, and with the help of the media, some Ghanaian Pentecostal/Charismatic pastors-prophets have commodified the gospel by employing various means of marketing to advertise, brand, and package religion as a consumer or spiritual product that can be bought to solve lifedebilitating issues. This article focuses on some of the contemporary practices of the neoPentecostal/Charismatic churches that are symptomatic of the commercialization and the commodification of religion. In so doing, the article attempts to tease out the positive and negative socio-economic implications of these practices. The work demonstrates that though there are some deleterious implications of the commodification of the gospel, the neo-Pentecostal/Charismatic churches, through such practices, have been able to raise substantial amounts of money to fund numerous social intervention projects that are helping transform the lives of people. Data used in this article was gleaned from the radio, television, and relevant literature.
\end{abstract}

Keywords: Pentecostalism, charismatics, consumer, commodification, socio-economic development. 


\section{Introduction}

\section{Anatomy of the religious, social, and political context for the emergence and expansion of Pentecostal/Charismatic Christianity in Ghana}

In the last two decades, the number of people in Ghana who have joined Pentecostal and/or Charismatic churches appears to have grown rapidly. The 2000 Population and Housing Census in Ghana indicates that $24.1 \%$ (out of $61.2 \%$ of the Ghanaian population who claimed to be Christians) were affiliated to Pentecostal Churches (Ghana Statistical Service, 2005). This Christian population, however, increased in the 2010 Census by $10 \%$ (i.e. from 61.2 $\%$ to $71.2 \%$ ). Of this, $28.3 \%$ are Pentecostals, Catholics $13.1 \%$, Protestants $18.4 \%$ and other Christians $11.4 \%$ (Ghana Statistical Service, 2012, p. 40). This growth in Pentecostal denomination as indicative of the 2000 and 2010 Population and Housing Census is largely attributed to the Charismatic and/or the neo-Pentecostal strand of the Pentecostal Churches in Ghana. This upward growth of the Pentecostal movement is not peculiar to Ghana but consistent with global patterns (cf. Attanasi, 2012, pp. 3-4). This brand of Pentecostalism, which is mostly referred to as the third strand of the Pentecostal movement in Ghana proliferated between the 1970s and 1980s and saw an exponential growth in the early 1990s (AsamoahGyadu, 2005; Omenyo \& Atiemo, 2006; Ojo, 2008).

To some extent, this growth pattern has been greatly influenced by the insistence on prosperity gospel and the adept use of modern media technologies. In this study, I use the term Pentecostal/Charismatic churches in reference to indigenous independent charismatic and neo-prophetic churches that emerged on the Ghanaian Christian scene between the late 1970s and early1990s, often referred to as the third wave or neo-Pentecostal movement (Asamoah-Gyadu, 2005; Omenyo \& Atiemo, 2006; Omenyo \& Arthur, 2013). Some of these churches include the Christian Action Faith Ministries (popularly known as the Action Chapel), International Central Gospel Church, Alive Chapel International, Perez Chapel International, and Life Ministry 
Worship Center. Apart from the neo-Pentecostals, there are also the traditional or classical Pentecostal churches which include the Apostolic Church, Church of Pentecost, Christ Apostolic Church, and Assemblies of God. While these broadly represent the second wave of Pentecostal churches in Ghana, the first generation is what scholars refer to as the African Independent Churches (AICs), generally perceived by Ghanaians as Sunsum Sore or spiritual churches. In this group are Musama Disco Christo Church (MDCC) and Apostle's Continuation Church, etc. (Asamoah-Gyadu, 2005; Omenyo \& Atiemo, 2006; Omenyo \& Arthur, 2013). The first two generations differ somehow from the neo-Pentecostal churches in terms of leadership and management style as well as emphasis on some doctrines, such as the prosperity gospel (Asamoah-Gyadu, 2005, pp.23-28). Nonetheless, they all share common practices, such as healing, prophecy, speaking in tongues (glossolalia), and vision.

A distinctive and/or shared theological denominator among neo-Pentecostal churches is the insistence on the need for one to be "born again" and experience the blessings, transformation, empowerment, success, and prosperity concomitant with the "born again" experience-material salvation which is largely expressed and more evident in healing and deliverance. Healing and deliverance are aimed at rebuking and binding demons, castigating witches and defying them by the power of God through Jesus Christ (AsamoahGyadu, 2005).

Remarkably, the emergence of the neo-Pentecostal/ Charismatic churches in the early 1980 s coincided with the rather aggravated socio-economic difficulties faced by citizens in subSaharan Africa. It will not be an overstatement to say that the context of socio-economic depravity and grime that most African countries witnessed during the 70s and 80s, for instance in Ghana and Nigeria, provided a context for the spread and growth of Pentecostal/Charismatic churches. This is largely so because the messages of Africa's neo-Pentecostals at the time centered on the precarious economic situation and the promises of God through 
Jesus Christ to alleviate his children from such economic quagmire through salvation which they read in the scripture. The late Nigerian theologian and historian Kalu (2009, p. 179) states precisely that the production of prosperity teachings in Africa ensued within the context of austere environment of African political economy in the 1980s when, in his own inventive semantic, "the earth groaned". Simply put, it was an era of brittle political systems that saw failing state resources, the commencement and implementation of Structural Adjustment Programs which brought in their wake enormous migration movements. In such a precarious context of economic deprivation and growing poverty rate, the prosperity gospel burgeoned as an immediate message to fill the "bowls of the poor" (Kalu, 2009, p. 186; see also Ogungbile, 2014, pp. 132-149). Significantly, the Pentecostal movement that has been at the margins of African Christianity became the carriers of the message and subsequently, exploded with enormous dynamism in the reshaping of the African religious landscape. "The competition for scarce resources intensified", asserts Kalu, culminated in fierce "religious competition" (Kalu, 2009, p. 180). This religious competition, Heuser (2015, p. 18) argues, "forged a Pentecostal political theology of prosperity, as it were; a prosperity formula with political dispositions and hegemonial power in public sphere". There was, as it were, an intense desire and incessant need to participate in and contribute to religious globalization from the African context of deprivation and socio-economic and political marginalization.

The messages of the Pentecostal/Charismatic churches at the time centered on motivating and encouraging people to have faith and survive even in the most unpropitious circumstances by harnessing the transcendent ends that come with salvation a "redemptive uplift", hinged on prosperity and transformation evidenced from pain and suffering. These messages seem to have appealed much to most people at the time because, as Karl Marx argues, religion has often been used to assuage the difficulties of people in modern work conditions. However, rather than viewing 
religion as a seepage, there can be "fitting", a reverberation, between religion and uncertainty; religion can serve to legitimate the inevitable choices individuals have to make (cf. Marti, 2012, p. 145). "So while it may be possible to see some forms of religion as an escape from modern conditions, it may be more fitting to see certain forms of religion as an embrace of these conditions, an implicit acknowledgement that the world has changed" (Marti, 2012, p. 145). Marti further argues, in this context, that Max Weber's insight on the adaptation of religion to every generation is helpful. According to Marti (2012), Weber notes that religion is most concerned with the alleviation of suffering. The nature of suffering - the difficult conditions of life- experienced in particular places and times becomes the most important determinant in the development of religious orientations and the nature of their ideals. In other words, we best understand the ideals set by religious orientations when we connect them to the concrete conditions confronted by individuals as they face challenges in their lives. For example, as already argued, in sub-Saharan Africa, economic liberalization and rising social inequalities spurred the expansion and spread of the neo-Pentecostal movement. Religious innovation such as spiritual warfare, prosperity gospel, and the use of the mass media became the engine for the promotion and growth of Pentecostalism.

Similarly, Bernice Martin (1998, p. 130) links the growth of Latin American Pentecostalism to economic changes. She tells a similar narrative of how individuals who were increasingly dissipated and disrupted both socially and economically relied on Pentecostal promises to alleviate their situation. This Pentecostal philosophy that enjoins conversion to upward mobility resonates with David Martin's (2002, p. 17) argument that Pentecostalism, generally fits into a new scheme of work that "requires a mobile self and indeed a powerful persona constantly redeployed to meet constantly changing situations and exigencies". Yong (2012, p. 28) contends precisely, from the prosperity angle, that one can see how in the last decades or so, particularly with the shift of the center of gravity of world Christianity toward the "global south", a religious 
economy of global renewal. According to Yong (2012, p. 28), this presupposes that we can use economic indices to quantify how religious movements compete for their market share of consumers. He also extrapolates how such indices and/or matrices involve actual economic scales that reflect how socio-economic factors are one important domain overlapping with the religious dimension that brings in coverts. In other words, he argues, "people are converting to Christianity at least in part because they are experiencing types of economic betterment" (p. 28).

Evidently, in the Ghanaian or African context, the connection between success in life, measured by conspicuous consumption and material worldviews, and divine grace thrives on the prosperity gospel and is inherently embedded within the consumeristic ethos of religion. In Africa, religion, is oriented towards everyday life. For the African, the manifest function of religion to control the powers of life and vitality is pivotal. The pragmatic-oriented function of religion is to make life possible and maintain it (food supply, human fertility, good life, and mutual relationships) and to safeguard it against all illnesses, misfortunes, enemies (devil, witchcraft) and death. For Pentecostals, especially, "this-worldly" ascetic and frugal lifestyle which was embedded in "escapist motive to build up counter-societies" in order to "immunize believers against the vicious operations of the devil in society", saw a redefinition in the 1980 s (Heuser, 2015, p. 20). The burgeoning of the Pentecostal movement in Africa in the 80s "redirected Pentecostal moral economy on the inner purity of a believer, who needs to be protected and saved from external temptations" by claiming a "practical relevance of bornagain belief ... and considered inner worldly success as a legitimate desire and material blessings" (Heuser 2015, p. 20). Thus, these new doctrines, much influenced by American word-of-faith preachers, capture succinctly, the attempt by African Pentecostal preachers to retool Christian theology to legitimate wealth and create new social spaces that are not controlled by "norms of religious piety that reside in traditional Christianity and African traditional religions but within the material realities of adherents" (Bonsu \& Belk, 2010, 
p. 306; see also Mbiti, 1975; Bediako, 2014; Weber, 1958).

The turn to affluence (wealth and good health) as an indicator of a "born again" belief has implications for religious consumerism and the subsequent commoditization of the gospel. The promotion of prosperity-oriented theology, to some extent, views religion as an economic product and reinforces an economic perspective on human life as it considers individual believers to be "human capital" and "human resources" whose economic value and potential must be realized. As argued by Gauthier, Woodhead and Martikainen (2013, p. 3), "consumer culture is the means of expression and actualisation of the modern project of the individualized self, as it provides a very particular set of material circumstances in which individuals come to acquire a reflexive relation to identity." The Canadian philosopher Taylor (2002, pp. 79-80) argues that, one way to explain the appeal of consumerism and its motivation, is to see how it provides a formidable vehicle for the massification and radicalization of the modern individualistic culture of authenticity and expressivity. For Pentecostals/Charismatics, material prosperity is enamored by a repertoire of success epitomized in the conspicuous consumption of modern products and persistent grandiosity, especially in the media. The emphasis on the prosperity gospel is to become more modern in outlook, sophisticated, and powerful as a symbolizing feature of one's right standing with God in terms of payment of tithes and offerings.

Further, the prosperity gospel is frequently accompanied by a discourse of deliverance from the enemy, Satan, and malevolent spirits, which are thought to attack believers and prevent them from enjoying the goods and blessings of God concomitant with salvation in the Lord Jesus Christ. Folarin (2007, p. 16) has defined prosperity gospel as "the teaching that solutions to people's problems of sin, sickness, poverty, and demon oppression are in Jesus Christ." As such, banishing these forces and subverting their schemes will enable believers to prosper; this is what Wariboko (2012, p. 45) dockets as the "spiritualist paradigm" in his categorization of the prosperity gospel. Simply put, salvation must be evident in both the 
spiritual and material realms and must become tangible (Volf, 1989, pp. 447-467). This supposed "redemptive uplift" as a consequence of one's salvation and belief in the Lord, when elusive, forces individuals to resort to religious functionaries with a reputation for spiritual power such as prophets, ministers, pastors, and malams ${ }^{1}$ to help diagnose their problems, mediate on their behalf between the physical and metaphysical and thereby, invoke divine blessings or offer possible solution or direction (akwankyere) in dealing with such situations. As Kalu (2003, p. 233) has noted, for example, African Pentecostals "reinforce the causality pattern in the African worldview before providing a solution beyond the purviews of indigenous cosmology" (see also Golo 2013, p. 373). Thus, childlessness, unemployment, illness, poverty, etc. are interpreted as satanic attacks, "and never as 'crosses' that God might give someone to bear, or as God-given experiences that might serve to deepen one's faith" (Währisch-Oblau, 2011, p. 65).

Anchoring and legitimatizing their major source of answers to life-debilitating issues from the Bible, Pentecostal/Charismatic hermeneutics on the prosperity gospel allows for more liberal interpretations that become a vanguard for supporting significant individual customization of religious practice (Meyer, 1999; Gifford 2004). These hermeneutics are usually produced, promulgated, and promoted by religious entrepreneurs' salespeople who create value for adherents, through the use of marketing techniques that facilitate and induce religious products or services as commodities, and place a heuristic value on religious message built on hope for those whose lives are otherwise heading nowhere. The leaning towards this kind of theology of the gospel that largely appeals to the transcendental orientation of the African particularly the Ghanaian Christian, engenders, a pathway for smooth commodification of the gospel. This is because, in an attempt by people to deal with their anxieties and vulnerabilities, they sometimes become gullible to religious entrepreneur salespeople (pastors-prophets) who sort of commoditize, abuse, and sell religious products or services as 1 Spiritualists from the Islamic tradition believed to possess some supernatural powers that allow them to diagnose and offer solutions to people's problems: poverty, sickness, unemployment, difficult marriages/relationships, etc. 
means of dealing with one's problems in life. Nonetheless, this does not suggest that individuals that patronize the services of these pastors-prophets are unable, or lack the ability, to make rational choices based on their prevailing circumstances. Rather, it evinces how religion and the worldview of mystical causality, by default, influence people to resort to religious providence to assuage their problems in life. Despite the criticisms that are mounted to some of the practices relating to religious commercialization and commodification, there is no doubt that religion, in some instances, has produced the very kind of results or solutions people want to their problems. As a result, religion continues to remain an optimal course of action in responding to people's problems in life.

The commercialization and commodification of the gospel take place in the broader spectrum of neo-liberalism. Arguably, neo-liberalism advocates free market systems and creates space for individual choices and freedoms. The free market system is created by neo-liberalism due to its emphasis on liberalization of state-owned enterprises. In a market society or consumer society, the tendency is that almost anything can be commodified, and the gospel cannot be an exception. In the consumer society, the gospel becomes increasingly understood as a product that can be marketed. As argued by Martikainen, Gauthier and Woodhead (2013, p. 15), "the social acceptance of neo-liberalism depends on a wider shift within western societies, one which has to do with the rise of consumerism as dominant cultural ethos." Thus, "consumption, consumerism, and hyper-mediatization participate in a wider phenomenon which is characterized by the ever-increasing pull of economics on all aspects of social and cultural life, along with the rapid rise of 'new' political economy of neo-liberalism, and the spreading of management and governance ideologies and practices" (Gauthier, Woodhead \& Martikainen, 2013, p. 2). The consequences are that, "consumerism as an ethos and matrix of lifestyle is inextricably tied to the development and democratization of communication technologies [and] together, they act as vectors for cultural globalization" (Gauthier, Martikainen \& Woodhead, 
2013, p. 16).

In this article, I present an example of the commodification of the gospel and its socioeconomic implications in Ghana. It is hoped that this article will contribute to existing literature on contemporary discourses on consumer culture and religion with a focus on neo-Pentecostal/Charismatic churches in Ghana. It attempts to take further the discussion by examining the positive and negative implications of the commodification of the gospel. Methodologically, I have relied extensively on the radio and television, and leveraged literature on the subject under discussion for most of the issues discussed in this article.

\section{Neo-Pentecostal/Charismatic churches and the commodification of the gospel}

In recent times, various forms of Pentecostal practices have grown rapidly in sub-Saharan Africa, including Ghana. These practices range from the sale of anointing oils, car stickers, wristbands to the charging of fees for counselling services, otherwise known as "consultation fees". Ultimately, the popularity of these services can be linked to an expansive interest in the personal well-being of individuals, and its relationship to religious and spiritual matters. Essentially, on an everyday basis, the Pentecostal/ Charismatic churches are finding new market techniques by utilizing the mass media, especially the radio, television and the print media to advertise their services and create a niche for themselves. Contrary to the assumptions of the modernization theories which predict a decline of the public role of religion, the free media space has had a profound impact on the public role of religion in Ghana and elsewhere in Africa. The opening up of radio and television stations in Ghana as a result of the free media space has given impetus to those who have the money to purchase airtime and mediate their programs to the public. Pentecostal/Charismatic churches, taking advantage of the liberalization of the media that accompanied Ghana's democratization, have inundated the media landscape with a host of religious programs (de Witte, 2005).

Religious practices among Pentecostals are purposely 
aimed at mediating the anointing of God and invoking the divine blessings and miracles of God for people and/or adherents to be delivered from material poverty. The promise of the Pentecostal movement in helping people to deal with their socio-economic situation through the transformative role of the Holy Spirit appeals very much to the situation of the ordinary Ghanaian/African. In a context where poverty and weak state welfare services mean a majority of the people are often left without any social intervention by the government, religion often becomes the alternative route to hope. Thus, a strong belief in God as one who can transform and assuage one's difficulties in life through the power of the Holy Spirit often yields good dividends for individuals and in the community of faith (Daswani. 2010, pp. 442-474). For most individuals, "religion constitutes a useful resource to improve their life. Often, individuals become affiliated with a religious congregation as a result of discontentment with their current life" (Köhrsen, 2015, p. 49). According to Köhrsen (2015, p. 49), "Pentecostalism in particular is notorious for attracting people, searching for a solution to a specific difficulty or looking for a general change in their life". He argues further that life-debilitating issues such as "diseases and health deficiencies, alcoholism, drug-dependency, poverty, unemployment, lack of direction in one's life, and depression are problems that are frequently mentioned by those converting to Pentecostalism" (Köhrsen, 2015, p. 49).

In helping to provide a ritual context and some interventionist strategies to deal with most of these problems, Pentecostal pastors-prophets engage in the commercialization of religious products ("salvation goods") that are meant to bring relief to frustrated individuals. In Africa (Ghana included), the expansive interest in personal well-being and health and its nexus of religious and spiritual matters remain ambivalent. For instance, the use of the mass media for marketing can be understood in the broader sense of its relatedness to the processes of commercialization and commodification of religious products. Religious products are complex and multifaceted phenomena which can be explained to include both tangible (books, stickers, wristbands, church 
paraphernalia's and/or religious objects) and intangible items often interpreted as "salvation goods" or "goods of pure belief" which include but not limited to religious services such as healing and deliverance, or others related to the promise of a reward for a better future (Usunier, 2016). Stolz (2008, pp. 59-60) attempts an integrated definition of religious products as "salvation goods":

an end or means to an end which is offered by a religion, embedded in a specific world-view and a system of life practices, and which may be aspired to or used by an individual or a social group. Salvation goods may be confined to certain points in time or lasting: set in the future or the present; transcendent or immanent. Individual or collective; ascetic or contemplative; aspired to actively or given to the individual by an external power.

In the marketing of intangible goods, the Pentecostal/ Charismatic church pastors-prophets are aware of the pragmaticoriented views of clients on the intersection of African religiosity and material realities. They are aware that in the worldview of their constituents lies the assumptions that "going through life is like a spiritual warfare and religious ardour may appear very materialistic as people strive to preserve their material sustenance in the midst of the machinations of pervasive evil forces" (Kalu, 2003, p. 230). This worldview is impinged with consumeristic tendencies along with its connections to marketing strategies that invigorate religious expression. The Pentecostal/Charismatic promise of freedom from demonic encumbrances and economic well-being for people allows them to facilitate the exploitation of the masses who are economically disgruntled and perplexed by life realities. Thus, as argued by Bonsu and Belk (2010, p. 312), "Pentecostal message appeals to a large number of people who have no alternative pathway to economic and social mobility." The Pentecostal view, as they argue, "blends the poor's reality into the realm of the spiritual cleverly using consumption as a salvation oriented religious tool for conversion" (p. 312). 
For instance, even though the use of anointing oil in the church is biblical, the commercialization of the religious substance in some neo-Pentecostal churches in Ghana by charging exorbitant prices for the product beyond its market value, makes the church a kind of business entity that is aimed at generating profit at the expense of the vulnerable consumer. Beyond the sale of anointing oil, products that are also commercialized in some neo-Pentecostal churches include water or "holy water", handkerchiefs, soaps, wristbands, and (car) stickers etc. The use of these items is expected to bring deliverance and God's favor upon those who buy them. In his article "Prosperity and poverty in the Bible: Search for balance", Asamoah-Gyadu (2015) bemoans how Christianity in Africa has become economically expensive due to the excesses emanating from prosperity gospelling. Focusing on the Pentecostal prosperity gospel and its ramifications for the economically disadvantaged individual, Asamoah-Gyadu highlights the recent initiatives of Bishop Eric Kwapong, one of Ghana's renowned charismatic worship leaders. As a professional consultant on Pentecostal/ Charismatic worship in Ghana, Kwapong organizes periodic gender-based worship services for professionals at the plush Holiday Inn Hotel, near the Kotota International Airport, Accra. The worship services are advertised either for professional men or professional women and are held on Friday evenings. According to Asamoah-Gyadu (2015), though there are no gate fees paid, "the specified target groups and the location means the worship services automatically rule out any underprivileged and materially poor participants". This is because "they simply would not have the requisite outfits expected and the levels of offerings required" (p.1). This, he argues, has made Christianity, and in this case corporate worship expensive and tailored to reach a certain privileged class in Ghana. This development, he forcefully contends, is "symptomatic of the commercialization or commodification of Christianity that comes with the prosperity Gospel" (Asamoah-Gyadu, 2015, p.1). Generally, the issue described by Asamoah-Gyadu is not peculiar to the ministry of Kwapong. In Ghana, we have Charismatic churches 
which hold their church services in hotel conference rooms, the National Theater, and other equally expensive conference centers where huge sums of monies are paid as rent. In the long run, the cost incurred in renting these facilities is passed on directly or indirectly to the people who attend these programs, in the payment of huge sums of offering and seed sowings.

In the following sub-section, I describe another development that also fits into the categorization of the commercialization or commodification of the gospel.

\section{The church as a marketplace}

In Ghana today, all the agents of commercialization of religion utilize the media (both print and electronic) to sell their wares of good health, prosperity, and financial breakthrough, offer security to people with an uncertain future, and promise deliverance from sickness and evil manipulations. Kalu (2010, p. 381) has argued that one of the issues that dominates the discourses on the use of media by Pentecostals in Africa is the issue of commercialization honed in the concept of market theory. The concept of market theory is built around the rational choice concept that profiles the religious space as being similar to a marketplace, and examines the commercialization of religion as a commodity, because messages are packaged as products in a competitive marketplace. He argues that marketing strategies enable religious businessmen to dupe gullible consumers by selling their books, videos, and audiotapes, and all manner of wares, using the sales techniques honed in the secular marketplace (Kalu, 2010, p. 382).

Some of the activities associated with the neo-Pentecostal/ Charismatic churches today are no less than the features that show an outright display of the market theory and the contemporary consumeristic nature of religion, where religious services or products have been commodified, packaged and sold to passive consumers who stand in constant need of such products or services. This heightened nature of the culture of consumerism, which is exacerbated by neo-liberal capitalist ideologies and tendencies, has hitherto influenced the way religion and religious lifestyles are 
practiced (Gauthier, Martikainen \& Woodhead, 2013, p. 1). Thus, individual Christians tend to look for the common good of religion with little or no attachment to godly values and good characters that ensure the growth in the Lord Jesus Christ. Religious practices among Pentecostals are purposely aimed at invoking the miracles or blessings of God for deliverance from material poverty. Religion is assumed as a finished product for passive consumers. The result is that messages are not created for the edification of the believer but for the success and economic well-being of the individual.

Within African cultures, concepts of illness and health are usually interpreted more in social and cultural terms than biological causation. Etiology and diagnosis in the context of traditional African thought, as Masamba ma Mpolo (1985, p. 9) rightly points out, pose the following basic question "who is the cause of my illness?"'. He adds that in this context of spiritual causality, "organically manifested symptoms are always the result of some external aggression" (p. 9). In the world of the traditional African, there is no chance-free incident, and the "unseen powers are held to be active also in the natural order" (Dickson, 1984, p. 49). In Africa, and also in Ghana, people usually associate misfortunes such as sickness or mysterious deaths with evil forces. When one loses hope due to failure or the inability to find solutions to such life-threatening problems, people resort to churches, and at times to spiritualists and other mediums through whom these problems could be averted or solved completely. Since most of these problems are believed to be spiritually instigated, religion (most often the church) becomes the only avenue which people turn to and rely upon to avert such calamities or seek a solution to their problems. It is not just any church, but usually churches where there is visible display of practices/features, such as prophecy, "word of knowledge", "word of wisdom", visions, healing, deliverance which are considered to be charismatic, more spiritual and can offer pragmatic solutions to people's pernicious problems. In Ghana, people mostly gravitate towards churches where the manifestation of these signs or spiritual gifts are visible. It is believed that with the operation of such gifts, the man of God will be able to diagnose their problems and offer 
possible solutions or directions (akwankyere) that one can employ in solving such troubles or problems in life.

It has become quite obvious that some "men of God" who claim to possess such gifts, or who claim to operate in the healing power of God's anointing, have become very popular, especially through their use of the media, and consequently, many people run to them/ their churches to seek solutions to their problems. In a religiously charged environment such as that of Ghana, one cannot prevent the masses from employing religious means in seeking solutions to perceived or real life-threatening issues. What is most striking, however, is the huge sums of money that are paid by clientele as "consultation fee" in order to have a personal contact with the "man of God" to help solve or deal with a situation. A telling example is when recently, while trying to search for a TV channel to watch at home after a day's work, and patiently waiting till I was able to catch some sleep, I chanced on a TV channel with the name Fire TV and I heard "the man of God", the General Overseer of Life Assembly Worship Centre, Pastor Christian Kwabena Andrews, popularly known as Osofo Kyiri Abosom, personally announce the increment of his consultation fee from 200 Ghana cedis (about $\$$ 50) to 300 Ghana cedis (about \$72). He announced that if people wanted to receive their "number" early, they had to send the money (consultation fee of 300 Ghana cedis) via a mobile money account number. This supposed acclaimed number is what one then will use to queue in order to get to see "the man of God".

In addition, the "man of God" announces that he now charges 500 Ghana cedis (\$ 120) for special appointments. However, if one wants to see "the man of God" for any special reason that can also be arranged through the payment of an undisclosed amount. The name, Osofo Kyiri Abosom, literally means "Pastor who detests traditional gods". It connotes an entanglement of the conflict between traditional religion and the consistent demonization of indigenous cultures by Pentecostals/Charismatics who constantly accuse traditional beliefs of being the instrument of, and/or being responsible for the retardation and misfortune of the local people. 
Deliverance, witchcraft cleansing, witchcraft eradication, land cleansing, and exorcism constitute Pentecostals' usual response to such traditional systems. All these are promoted in the full glare of the television, because healing is one of the main concerns in Africa. Osofo Kyiri Abosom claims to have a solution to most of the problems that are encountered by people on a daily basis and hence, he offers them hope to alleviate their fears by burning traditional shrines as well as by selling different kinds of anointing oil purposely made to solve various problems believed to be instigated by the devil. The setting ablaze of the shrines and the sale of the anointing oils are all shown and marketed on the digital television station, Fire TV owned and operated by the Life Assembly Worship Center. Arguably, the practice of commercializing religious services and/ or charging of consultation fee before seeing a "man of God" are not peculiar to the ministry of Osofo Kyiri Abosom. There are many such practices that currently occur in many churches in Ghana. In effect, there are many church services in which clients are asked to pay for the services rendered to them by the "men of God". Also practiced and popularized on a daily basis is the sale of anointed car stickers, anointed oils, wristbands, etc., as channels of supernatural powers that can prevent any attack from the devil.

The charging of fees for services rendered by pastors to their church members is what has been interpreted by AsamoahGyadu (2013, p. 80) as "transactional giving". According to him, transactional giving "stimulates divine responses to human desires" and is mainly reciprocal. He cites the example of a "man of God", by name Prophet Ewusi-Brookman who, after an anointing service at an International Central Gospel Church in Takoradi, announced that it was the turn of the worshippers to "bless the man of God" for his prophetic impartation during a week-long service (AsamoahGyadu, 2013, p. 80). In such a context, "blessing the man of God" meant giving a special "prophetic offering" (p. 81) to the prophet. I have also personally witnessed the same approach from "men of God" in most of the charismatic church services I have visited in Ghana. According to Asamoah-Gyadu (2013), 
although transactional giving occurs on the basis of scripture interpretation, it takes on added significance within the African context because giving is an important part of religious negotiations in traditional shrines. In African traditional religions generally, ancestors and deities are fed periodically as a way of sustaining cultic relationship that enable the benefits of health, abundance, longevity, and various forms of prosperity to flow from the transcendent realm towards the human realm. (p. 81)

So often, in Africa, personal and communal misfortune is explained as/to be the non-fulfilment of religious obligations, such as not performing appropriate sacrificial rituals or neglecting ancestors and deities. Thus, transactional giving (payment of "consultation fees") among Pentecostal/Charismatic churches resonates largely with the primal imagination in Africa, by which people give to benevolent transcendent helpers with the aim of creating auspicious circumstances and the realization of material blessings (AsamoahGyadu, 2013, p. 81). However, this does not defeat the grip of neoliberal ideologies by neo-Pentecostals since even though, they tend to be more modern in their outlook by embedding and integrating into their practice, modernist and economic ideas in the society through a representation of a radical break from local cosmologies, Pentecostal/Charismatic churches are caught up in the cultural web of replicating or re-enforcing certain traditional worldviews or religiosities thereby creating a kind of both continuity and discontinuity in their practices (Meyer, 1998; Robbins, 2003).

\section{Commodification of the gospel and its socio-economic implications}

It is in the attempt by neo-Pentecostals to address, in a variety of ways, the socio-economic challenges that the faithful face in life, that the commercialization and the commodification of the gospel become evident. Individuals who, despite the promises of God in the scriptures find their life dreams elusive or shattered due 
to economic depravity and bad leadership, often become gullible. As a result, most of these individuals in the haste to "turnaround" a life of squalor that is heading nowhere become gullible to the dictates of "men of God" who present themselves as agents of God with solutions to life challenges. By so doing, some take advantage of the vulnerability and the gullibility of such individuals by selling their religious wares and charging exorbitant prices for services rendered to them all in the name of helping them solve their unwanted problems and challenges in life.

However deleterious some of these practices may be, the Pentecostal promise as a source of hope to individuals dislocated by present economic challenges that they, too, will in time, become partakers of God's divine blessings and engage in the contemporary globalization and its associated material trappings (Maxwell, 1998; Gifford, 2004) allows adherent to build individual religious capital (Innaccone, 1990), that is employed to gain economic capital with implications for socio-economic development. As argued by Brouwer, Gifford, and Rose (1996),

this religious tradition helps people exercise control in a seemingly uncontrollable world through strict standards of 'right living.' Incomprehensible cycles of poverty and violence are made comprehensible through an all-encompassing theology and by the personal authority of the pastor. And, access to an everyday miracle religion empowers people; it gives them hope of negotiating insurmountable obstacles of an unknown future. (p. 179).

In this section, I present some of the positive and negative effects of the commodification of the gospel and tease out their implications for socio-economic development. I do so because though the commercialization and the commodification of the gospel have some deleterious implications on the materially poor, they, nonetheless, serve as conduits through which funds are raised to support socio-economic policies and initiatives by Pentecostal/ Charismatic churches. In the first subsection, I discuss some of the 
positive initiatives undertaken by Pentecostal/Charismatic churches that support and foster socio-economic development. The second subsection will concentrate on some of the negative implications of the commodification of the gospel.

\section{Positive impact}

First, in Ghana, neo-Pentecostal/Charismatic churches, since their emergence over the last three decades, have sought not only to be recognized in the proclamation of the gospel of Christ Jesus but also, to help cater for the needs of the people in the society by providing certain basic essential amenities. Neo-Pentecostal/ Charismatic churches have over the last years been lambasted for promoting lavish lifestyles and not contributing to the welfare of the poor. Though there might be criticisms on the adherence to the doctrine of prosperity gospel and its subsequent commercialization and commodification, it is evident that Pentecostals are, to some extent, redirecting their wealth into social welfare initiatives in a broader context for the improvement of lives in the society. Thus, as argued by Miller and Yamamori (2007, p. 32), Pentecostal/ Charismatics are being "progressive" in that they work to address "the social needs of people" and they do not restrict their social service provision only to their members.

The Pentecostal churches, through their ingenuity and innovativeness, have provided social amenities such as schools (kindergarten up to University), hospitals or clinics, opened up businesses, dug water boreholes aimed at addressing societal challenges and also, complemented government effort in providing such services. Some examples of the provision of social services or amenities in Ghana will throw more light on this. In Ghana, for example, almost all the leading Pentecostal/Charismatic churches have established private universities and health centers. Notable ones include Central University funded by Mensa Otabil's International Central Gospel Church (ICGC), Dominion University College funded by Archbishop Duncan Williams' Christian Action Faith Ministries (CAFM) and Perez University College by Bishop Agyinsare's Perez Chapel International (PCI). 
These investments by Pentecostal/Charismatic churches have become necessary, since successive governments have had difficulties in managing the economy over the years due to internal issues like corruption and other external shocks like increases in the world prices of crude oil and the fluctuations in export commodities. Despite various policy interventions like the International Monetary Fund's Structural Adjustment Programs, the Economic Recovery Programme, and the signing up for the Highly Indebted Poor Country (HIPC) status, the Ghanaian economy is still challenged, thus making the provision of social services and infrastructural development, extremely difficult tasks for an elected government to grapple alone with (Meyer, 2004; Bawumia, 2014) Pentecostals are thus filling the gaps seemingly created by governments' failure to meet the basic needs of the populace just as mainline churches, and para-church groups, and civil societies have been doing over the years (Meyer 2004; Bawumia, 2014). Conversely, Pentecostals, just like the mainline churches, are now stakeholders in the national economy and development. This means that inasmuch as governments still hold power, local movements, such as the Pentecostal churches are also asserting their place in civic affairs (Wuthnow, 2007).

Second, the commodification of the gospel, which takes place in the broader context of healing and deliverance, success, and prosperity from a theological perspective provides a window to "render meaningful the individual's experience of unpredictable changes in personal economic well-being" (Isabelle, 2007, p. 421). The prosperity gospel, a subset of the deliverance ministry, projects the church as a category of non-state actor of enlightenment to people as it is believed that God rewards faithful Christians with good health, financial success, and material wealth. Thus, adherents of the Pentecostal movement approach their religious responsibilities with the view to blending the material and the spiritual through the giving of offerings and seed sowing to create the auspicious atmosphere for the trapping of divine blessings. The deliverance and/or the religious products that people pay for (commodification) 
are associated with the promise of an escape from life's constraints and burdens. As Onyinah (2004, p. 337) contends, the real sources of the problems in Africa are the controlling powers of various territorial spirits such as poverty and idolatry. He maintains that within this post-modern world, where "homogenous plurality with fragmentation of cultures, traditions, ideologies, forms of life, language games, or life worlds" is a key feature, deliverance is amenably received. The linkages of the consumption of religious services and/or product purchased to individual faith and personal salvation (deliverance) through the Spirit of God inherent in such religious wares filter economic experiences through the lens of faith and miracles touching the lives of those who consume the spiritualized commodified goods. The consumption of the religious goods and/or services is embedded within the view that the manifest presence of the Holy Spirit that comes with the consumption of such religious goods effects happiness, prosperity, and a breakthrough, and so, provides the theological basis for "an often astonishing level of self-confidence, persistence against all odds, energy and ingenuity and a willingness to try anything - and then call the result the Lord's miracle" (Martin, 1995, p. 111)

\section{Deleterious implications}

First, the marketization and sale of religious wares such as handkerchiefs, water, and anointing oil as therapeutic substances for healing exemplify spiritual materialism since these products become spiritual commodities that one can purchase for the purpose of healing or deliverance from demonic bondage. The sale of these religious products is completely out of keeping with New Testament theology. This is because, God's gift of healing is available for any child of God who diligently prays to Him and seeks His face for his or her healing. It is clear from Acts 18:14-24 that one cannot purchase the gift of God with money. It is rather the indwelling of the Holy Spirit and contrite heart with God and faith that bring healing and deliverance to the needy and afflicted. People who arduously pray and seek the face of God will receive their healing. The Holy Spirit gives the ability to heal the righteous 
people through their faith in God's word. It is faith in God that brings the healing anointing and not the mere payment of money for these items. The effect of these practices is that churches are likely to become too materialistic and not hold in high esteem the power of God in their lives to heal or solve life-threatening situations. This is not, however, to speak against material success. Nonetheless, materialism could be abhorred. Materialism means the unbridled crave for material things as if they were an end in themselves. The Lord Jesus Christ spoke much against materialism. Of the lot, the following text reveals what the notions of Christ are on materialism:

Do not store up for yourselves treasures on earth, where moth and rust destroy, and where thieves break in and steal. But store up for yourselves treasures in heaven, where moth and rust do not destroy, and where thieves do not break in and steal. For where your treasure is, there your heart will be also. ... No one can serve two masters. Either he will hate the one and love the other, or he will be devoted to the one and despise the other. You cannot serve both God and Money. (Matthew 6:1921, 24)

This might lead people to become material-oriented and passive consumers rather than seekers of God's word that will forever abide in them, heal their diseases, and transform their lives through the empowerment of the Holy Spirit.

Second, the commodification of religious services does not engender any promise of economic blessings. That is, in one way or the other, the attempt by Pentecostal pastors-prophets to always convince people via aggressive advertisement and marketing in the media to trade in or purchase their religious wares for a breakthrough, does not always result in the socio-economic transformation of consumers or adherents. As rightly noted by Iannaccone (1992, p. 126), most religious commodities stand beyond the range of human evaluation. In this case, one would ask, whether or not there can be a modus operandi for measuring the supposed socio-economic 
well-being or transformation that is expected in individual's life after the consumption of religious products or services. The obvious answer, which is no, is predicated on the fact that when goods and services are being purchased, they "divulge the information about their characteristics to a differing extent" (Britnitzer, 2003, p. 160 cited in Hero, 2016, p. 76).

Revealingly, information economics differentiates between goods and services of three categories: first, those whose quality the consumer can check before buying them ("inspection goods"), second, those whose quality is only revealed to the consumer during consumption ("experience goods"), and finally, the goods whose quality largely remains in the dark even after consumption ("credence goods") (cf. Ekelund, Mixon \& Ressler 1995; Richardson 1999; Dulleck \& Kerschbamer, 2006). Since, in the arena of religious goods or spiritual commodities, there are "as good as no legal guarantees or equivalent securities as to the 'quality' or the 'benefit', potential interested parties find themselves in a situation of uncertainty" (Hero, 2016, p. 76). In this case, it means that the uncertainty surrounding the religious goods or products and their effect can only be built on trust (Martin 2015, p. 310). However, the lack of specific criteria to judge the "quality" or the supposed breakthrough for transformation inherent in the commoditized religious objects or services portends the collapse of trust in the services. This means that in the long run, people will no longer trust in the efficacy of religion as a means of solving their unwanted problems or difficulties in life. Since, there might not be any clear obvious benefits to be reaped from offerings, adherents might have difficulty assessing their breakthrough and prayer for economic transformation and societal well-being. This obfuscates the socioeconomic and transformation agenda attached to the consumption of the religiously commoditized goods or services because it lacks the capacity to produce any sustained economic transformation.

Third, the commodification of the gospel has the tendency to inculcate in adherents a certain kind of contractual relationship that only makes one's relationship with God "conceived of in purely 
instrumentalist, impersonal and economic cost/benefits terms". Thus, to borrow the exacts words of Lindhart (2015, p. 311), "to put it in an admittedly extreme way, there is a certain danger of divine blessings turning into simple commodities that can be advertised and (supposedly) purchased in much the same way as goods on a supermarket shelf'. In this situation, the church primarily becomes an avenue to improve people's lives, enhance their self-esteem, and give them a sense of purpose and direction. From the perspective of Conradie (2010, p. 105), consumeristic religion becomes "more passive, more individual and more private. It follows the patterns of self-gratification rather than service" (p. 105). Thus, the emphasis on "religious experience", "inwardness and feeling (and thus on spirituality) as opposed to religious institutions." This oft-times makes religion assume "a narcissistic self- centered therapeutic exercise in order to fathom the depths of the inner self-far removed from concern for justice" (Conradie, 2010, p. 105). This builds a kind of individual spiritual capitalism that takes away communal and personal values needed to build social capital and social cohesion for collective socio-economic development.

\section{Conclusion}

The discussion made in this article features prominently the practices of contemporary Pentecostal/Charismatic churches that are symptomatic of the commercialization and commodification of religion. The article has demonstrated how some Pentecostal/ Charismatic churches with their theology of prosperity gospel material wealth and well-being evidenced in salvation, embed aggressive advertisement and branding strategies to make religion appealing to the masses whose hope is lost in an austere economic environment. Such Pentecostal/Charismatic churches, with their doctrine of salvation and ritual praxis (healing and deliverance), provide adherents tools to respond to the vagaries of harsh socioeconomic situation and life challenges. By so doing, they emphasize a post-modern conception of religion that favors religious customization characterized by individual selection of doctrine and practice. 
Again, although the extensive emphasis on the ability of religion to assuage life difficulties makes religion a kind of a commodified product, it, nonetheless, has some socio-economic implications. An important aspect is that through such means, the neo-Pentecostal/Charismatic churches have been able raise huge sums of money and engaged in the re-distribution of their wealth in areas, such as education and healthcare. However, the capitalistic practices of some of the Pentecostal/Charismatic churches also have very negative implications for the practice of religion and Christianity, in general. This is because, it devalues Christian commitment and makes one's relationship with God a mere contractual market relationship. As Horsfield (1984, p. 84) suggests from a North American context, the insistence that people might purchase religious goods or sow a seed in order to be blessed, saved, or prosperous may very easily lead to a "return to the purchasing of indulgencies, with the only proviso being one's willingness to pay the required amount in order to set the mechanisms of miracle-working in motion". The result is that the poor, outcasts, marginalized, and the socially disadvantaged or helpless, who were actually at the center of the ministry of the Lord Jesus Christ, are ignored because they may not have the finances to purchase their healing and also, may be disregarded because they do not show the symbols and good images of the gospel of prosperity. This means they will also lose any kind of social capital, social cohesion, and reproduction that are necessary ingredients for socio-economic well-being, development, and transformation. 
Benyah, F./ Commodification of the gospel and the socio-economics in Ghana

\section{References}

Asamoah-Gyadu, J. K. (2005). African Charismatics: Current developments within independent indigenous Pentecostalism in Ghana. Leiden: E.J. Brill.

Asamoah-Gyadu, J. K. (2013). Contemporary Pentecostal Christianity: Interpretations from an African context. Oxford: Regnum International; Akropong-Akuapem, Regnum Africa.

Asamoah-Gyadu, J. K. (2015). Prosperity and poverty in the Bible: Search for balance. Lausanne Movement. Retrieved from https://www. lausanne.org/content/prosperity-and-poverty-in-the-bible-search-forbalance.

Attanasi, K. (2012). Introduction: The plurality of prosperity theologies and Pentecostalisms. In K. Attanasi \& A. Yong (Eds.), Pentecostalism and prosperity: The socio-economics of the Global Charismatic Movement (pp. 1-12). New York, NY: Palgrave MacMillan.

Barker, I.V. (2007). Charismatic economics: Pentecostalism, economic restructuring, and social reproduction. New Political Science, 29(4), 407-427.

Bawumia, M. (2014). Restoring the value of the cedi. Visiting professor of economic governance. Paper presented at the distinguished speaker series lecture, Central University College, Ghana.

Bediako, K. (1995). Christianity in Africa: The renewal of a non-western religion. Maryknoll, NY: Orbis Books.

Bonsu, S.K., \& Belk, R. W. (2010). Marketing a new African God: Pentecostalism and material salvation in Ghana. International Journal of Nonprofit and Voluntary Sector Marketing, 15, 305-323.

Brinitzer, R. (2003). Religion. Cited in Hero, M. (2016). The marketing of spiritual services and the role of the religious entrepreneur. In J.-C. Usunier \& J. Stolz (Eds.), Religion as brands: New perspectives on the marketization of religion and spirituality (pp. 75-87). New York, NY: Routledge.

Brouwer, S., Gifford, P., \& Rose, S. (1996). Exporting the American gospel. New York: Routledge.

Conradie, E.M. (2010). Christianity and a critique of consumerism: A survey of six points of entry. Wellington: Bible Media.

Daswani, G. (2010). Transformation and migration among members of a Pentecostal Church in Ghana and London. Journal of Religion in Africa, 40 (4), 442-474.

De Witte, M. (2005). The Holy Spirit on air in Ghana. Media Development, 52 (2), 22-26.

Dickson, K. A. (1984). Theology in Africa. Maryknoll, NY: Orbis.

Dulleck, U., \& Kerschbamer, R. (2006). On doctors, mechanics, and computer specialist - the economics of credence goods. Journal of Economic Literature, 44, 5-42. 
Ekelund, R.B., Mixon, F.G., \& Ressler, R.W. (1995). Advertising and information: An empirical study of search, experience and credence goods. Journal of Economic Studies, 28, 33-43.

Gauthier, F., Martikainen, T., \& Woodhead, L. (2013). Introduction: Religion in market society. In T. Martikainen and F. (Eds.), Religion in the neoliberal age: Political economy and modes of governance (pp. 1-18). Farnham \& Burlington: Ashgate Pub. Company.

Ghana Statistical Service. (2005). 2000 Population and housing census. Accra: Ghana Statistical Service

Ghana Statistical Service. (May 2012). 2010 Population \& housing census: Summary report of final results. Retrieved from http://www. statsghana.gov.gh/docfiles/2010phc/Census2010 Summary report of final results.pdf.

Gifford, P. (2004). Ghana's new Christianity: Pentecostalism in a globalizing African economy. London: Hurst \& Co.

Golo, B.K. (2013). Africa's poverty and its neo-Pentecostal "liberators": An eco-theological assessment of Africa's prosperity gospellers. Pneuma, $35,366-384$.

Heuser, A. (2015). Religio-scapes of prosperity gospel: An introduction. In A. Heuser (Ed.), Pastures of plenty: Tracing religio-scapes of prosperity gospel in Africa and beyond (pp. 15-29). Frankfurt am Main: Peter Lang.

Horsfield, P.G. (1984). Religious television: The American experience. New York: Longman.

Iannaccone, L.R. (1990). Religious practice: A human capital approach. Journal for the Scientific Study of Religion, 29 (3), 297-314.

Iannaccone, L.R. (1992). Religious markets and the economics of religion. Social Compass, 39, 123-131.

Kalu, O.U. (2003). "Globecalisation” and religion: The Pentecostal model in contemporary Africa. In J. L. Cox \& G. Haar (Eds.), Uniquely African? African Christian identity from cultural and historical perspectives (pp. 215-240). Asmara, Eritrea: African World Press.

Kalu, O.U. (2009). From the end of history to the beginning of poverty: Poverty and social engagement in contemporary African Christianity. In K. Koschorke (Ed.), Falling walls: The year 1989/90 as a turning point in the history of world Christianity (pp. 177-194). Wiesbaden: Harrassowitz.

Kalu, O.U. (2010). The big man of the big God: Popular culture, media and African Pentecostal missionary strategy. In W. K. Kalu, N. Wariboko \& T. Falola (Eds.), Christian missions in Africa: Success, ferment and trauma Vol. 2 (pp. 373-395). Asmara, Eritrea: African World Press.

Köhrsen, J. (2015). Pentecostal improvement strategies: A comparative reading of African and South American Pentecostalism. In A. Heuser (Ed.), Pastures of plenty: Tracing religio-scapes of prosperity gospel in Africa and beyond (pp. 49-64). Frankfurt am Main: Peter Lang. 
Lindhardt, M. (2015). Are blessings for sale? Ritual exchange, witchcraft allegations, and the de-alienation of money in Tanzanian prosperity ministries. In A. Heuser (Ed.), Pastures of plenty: Tracing religioscapes of prosperity gospel in Africa and beyond (pp. 309-321). Frankfurt am Main: Peter Lang.

Ma Mpolo, M. (1985). Perspective on African pastoral counselling. In M. Mpolo \& W. Kalu (Eds.), The risks of growth: Counselling and pastoral theology in the African context (pp. 1-17). Nairobi: Uzima Press.

Marti, G. (2012). "I determine my harvest": Risky careers and spiritguided prosperity in Los Angeles. In K. Attanasi \& A. Yong (Eds.), Pentecostalism and prosperity: The socio-economics of the global charismatic movement (pp. 130-150). New York, NY: Palgrave MacMillan.

Martin, B. (1995). New mutations of the protestant ethic among Latin American Pentecostals. Religion, 25, 101-117.

Martin, B. (1998). From pre- to post-modernity in Latin America: The case of Pentecostalism. In P. Heelas (Ed.), Religion, modernity and postmodernity (pp. 102-146). Oxford: Blackwell.

Martin, D. (2002). Pentecostalism: The world, their Parish. Oxford: Blackwell. Maxwell, D. (1998). "Delivered from the spirit of poverty?" Pentecostalism, prosperity and modernity in Zimbabwe. Journal of Religion in Africa, 28(3), 350-373.

Mbiti, J.S. (1975). Introduction to African religions. London, Heinemann.

Meyer, B. (1998). Make a complete break with the past: Memory and postcolonial modernity in Ghanaian Pentecostal discourse. In R. Werbner (Ed.), Memory and the postcolony: African anthropology and the critique of power (pp. 182-208). London: Zed Books.

Meyer, B. (1999). Translating the devil: Religion and modernity among the Ewe in Ghana. Edinburgh: Edinburgh University Press.

Meyer, B. (2004). "Praise the Lord": Popular cinema and Pentecostalite style in Ghana's new public sphere. American Ethnologist, 31(1), 92-110.

Miller, D. E., \& Yamamori, T. (2007). Global Pentecostalism: The new face of Christian social engagement. Berkeley, CA: University of California Press.

Ogungbile, D. (2014). African Pentecostalism and the prosperity gospel. In C. R. Clarke (Ed.), Pentecostal theology in Africa (pp. 132-149). Eugene, OR: Wipf \& Stock.

Ojo, M. (2008). The growth of charismatic movements in northern Nigeria. Ogbomso Journal of Theology, 13 (2), 88-95.

Omenyo, C. N., \& Arthur, W. A. (2013). The Bible says! neo-prophetic hermeneutics in Africa. Studies in World Christianity, 19 (1), 50-70.

Omenyo, C.N., \& Abamfo O. A. (2006). Claiming religious space: The case of neo-prophetism in Ghana. Ghana Bulletin of Theology, 1 (1), 55 - 68. 
Onyinah, O. (2004). Contemporary "witchdemonology" in Africa. International Review of Mission, 93, 330-345.

Richardson, H. (1999). The credence good problem and the organization of health care markets. Texas A \& M University: Mimeo.

Robbins, J. (2003). On the paradoxes of global Pentecostalism and the perils of continuity thinking. Religion, 33(3), 221-231.

Stolz, J. (2008). Salvation goods and religious markets: Integrating rational choice and Weberian perspective. In J. Stolz (Ed.), Salvation and religious markets (pp. 51-80). Bern: Peter Lang.

Taylor, C. (2002). Varieties of religion today: William James revisited. Cambridge, MA: Harvard University Press.

Usunier, J. (2016). "9591": The global commoditization of religions through GATS, WTO, and marketing practices. In J.-C. Usunier \& J. Stolz (Eds.), Religion as brands: New perspectives on the marketization of religion and spirituality (pp. 27-43). New York, NY: Routledge.

Volf, M. (1989). Materiality of salvation: An investigation in the soteriologies of liberation and Pentecostal theologies. Journal of Ecumenical Studies, 26 (3), 447-467.

Währisch-Oblau, C. (2011). Material salvation: Healing, deliverance, and "breakthrough" in African migrant churches in Germany. In C. G. Brown (Ed.), Global Pentecostal and charismatic healing (pp. 61-80). Oxford, NY: Oxford University Press.

Wariboko, N. (2012). Pentecostal paradigms of national economic prosperity in Africa. In K. Attanasi \& A. Yong (Eds.), Pentecostalism and prosperity: The socio-economics of the global charismatic movement (pp. 35-59). New York, NY: Palgrave MacMillan.

Weber, M. (1958). The Protestant ethic and the spirit of capitalism. New York: Scribner's. Wuthnow, R. (2007). Introduction. In encyclopedia of politics and religion. Washington: Congressional Quarterly Press.

Wuthnow, R. (2007). Introduction. In encyclopedia of politics and religion. Washington: Congressional Quarterly Press.

Yong, A. (2012). A typology of prosperity theology: A religious economy of global renewal or a renewal economics? In K. Attanasi \& A. Yong (Eds.), Pentecostalism and prosperity: The socio-economics of the global charismatic movement (pp. 15-33). New York, NY: Palgrave MacMillan. 